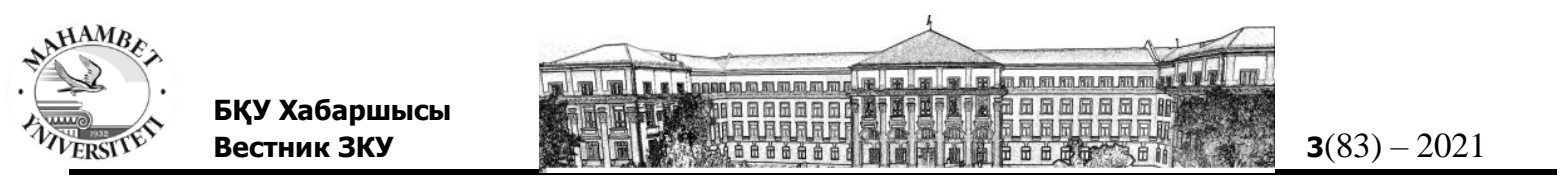

UDC 378.147:004.77

IRSTI 16.01 .45

DOI 10.37238/1680-0761.2021.83(3).2

${ }^{1}$ Keldibay A.T.*, ${ }^{2}$ Zhusupova R.F.

\author{
${ }^{1}$ Kyzylorda University named after Korkyt ata, Kyzylorda city, Kazakhstan \\ ${ }^{2}$ L. N. Gumilyov Eurasian National University, Nur-Sultan city, Kazakhstan \\ *Correspondence: ainura_1996.kz@mail.ru
}

E-mail: ainura_1996.kz@mail.ru,rozazhusupova@mail.ru

\title{
NEW FORMS OF USING WEBSITES IN ONLINE ENGLISH TEACHING
}

\begin{abstract}
Annotation. The article is dedicated to using educational Internet resources for teaching English online. This article examined the concepts and essence of educational Internet resources, what criteria teachers should follow when choosing Internet resources, what features of using a foreign language with the help of Internet resources should be considered. This article deals with the phenomenon of globalization of education, which entailed the significant influence of the Internet and computer technology on the methodology of teaching English during the pandemic. It also describes modern ideas and trends of foreign colleagues in teaching a foreign language. Furthermore, this work outlines the types of Internet resources that can be used in teaching a foreign language at the present stage of education. The Internet is a huge source of information about the language being studied, the culture and traditions of a foreign language, its realities and characteristics. The information technology has played an important role in English language teaching and it has offered a better tool to explore the new teaching method. The purpose of the article is the use of information technology in increasing the effectiveness of teaching English, developing students' creative abilities at English lessons. There given various available online tools in the Internet for the students and recommend the modern tools for English teachers.
\end{abstract}

Keywords: internet, internet resources, education, English language, online teaching, internet services, technology, websites.

\section{Introduction}

In modern society, the role of foreign languages is becoming truly irreplaceable. Knowledge of a foreign language makes it possible to join the world culture, to use fully the potential of Internet resources.

Currently, new communicative technologies and websites are being intensively introduced into all areas of our life, including the educational process. In this regard, there is a need to develop a methodology for using Internet resources in teaching a foreign language. Even today we can already say that the pandemic has had a significant impact on the development of new methods of teaching foreign languages through the Internet and computer technology.

Markee indicates that the spread of information technology worldwide is strongly linked with the diffusion of the English language. To put it differently, it can be stated that while English has contributed to the proliferation of this technology, the information technology has also boosted the diffusion of English through Internet communication. Furthermore, because several studies in scientific and technological areas have been conducted in English, people are to have a basic knowledge of English to conduct research. According to Zhu, that people need knowledge of 


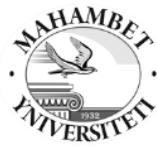

English to obtain information has promoted the status of English to lingua franca which in turn has influenced the language teaching in the world [1].

The possibilities of using Internet resources are enormous. The global Internet creates conditions for obtaining any information necessary for students and teachers: regional geographic material, news from the life of young people, articles from newspapers and magazines, necessary literature, etc. Students can take part in testing, in quizzes, competitions, Olympiads held on the Internet.

The global Internet offers many useful resources for foreign language teachers. These are special programs for teaching foreign languages, as well as authentic material that the teacher can select.

As an information system, the Internet offers its users: New information technologies in teaching English to create their own home page and place it on a Web server search engines (Alta Vista, Hot Bob, Open Text, WebCrawler, Excite) reference directories (Yahoo!, InfoSeek / Ultra Smart, Look Smart, Galaxy). These resources can be actively used in the lesson! e-mail (e-mail) teleconferences (usenet) video conferencing conversation on the network (Chat)

Students can take part in tests, quizzes, contests, olympiads held on the Internet, correspond with peers from other countries, participate in chats, video conferences, etc.

A potential positive of online education was the idea that parents would become more familiar with their children's study habits and consequently more able to play a positive role in their learning. For example, children hoping to succeed in online education benefit from being focused and resilient, and evidence shows that parents can substantially support their children's efforts to develop such habits [2].

This assumes a home where parents are willing and able to promote their children's education. Unfortunately, for many children their home is not a nurturing or safe environment. Around the world, the imposition of social isolation has led to a rise in domestic abuse and family violence [3]. In these circumstances, parental involvement may not have a positive effect.

In recent years, online learning has been widely used around the globe [4]. To an extent, the spread of online learning is limited by access to the Internet, communal infrastructure, and communal/individual technological resources; where these factors are lacking, families have difficulty in participating in online educational opportunities [5].

Some scientists say that the Internet is one of the factors that has a significant contribution to promoting the use of computers for language learning. For the first time, foreign language learners can now communicate inexpensively and quickly with other students or speakers of the studied language throughout the world. In addition, Dundee also mentioned one of the advantages of using computers and the Internet in the practice of teaching and learning languages especially for teachers. He mentioned that, in essence, the computer and live language communication have now become a common resource, always available to the target audience on the board. Teachers and students can use the board to show the contents of the CD-ROM and the Internet, and this content can be annotated, illustrated, saved, and printed. In most situations, this content can be used as a special resource [6].

The online learning system has long been in demand in the world, is very effective and has excellent indicators and ratings. We know it well for the example of language courses or programs for obtaining a second higher education in European or American universities.

Such a system provides many more possibilities than we imagine. Firstly, you can learn from both home and anywhere in the world. For example, if a child has a disability, falls ill or is in another country during a quarantine period of periodic border closings. He receives a full-fledged education on an equal basis with his peers without any restrictions. Online education offers a wide range of educational services that are not limited by time or space.

Secondly, the online learning system is a fairly flexible and adaptive product, it offers students and teachers such opportunities that cannot be achieved using only traditional teaching methods. The use of digital technologies allows students to choose a suitable pace of learning, a comfortable principle of material presentation, lesson duration, and additional information. 


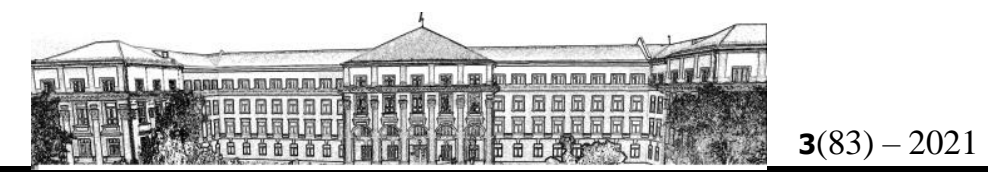

And thirdly, online learning and work with electronic textbooks help to improve the efficiency of the educational process, increase academic performance and develop skills in working in a digital environment.

Digital teaching materials offer optimal, personalized learning opportunities. International experts note that, unlike paper textbooks, the use of digital technologies in the educational process allows students to study the selected topic in depth or refer to the previous material for repetition. This is made possible by a modern search engine and an integrated learning environment function. In other words, e-textbook teaching is most effective when it meets the individual needs and learning goals of learners [7].

\section{Materials and methods of research}

There are several types of Internet services that can be used for independent work of students:

1. Hotlist (list by topic) - is a kind of list of sites with texts on the topic under study. If the user wants to create it, then he needs to enter a keyword in the search engine.

2. Multimedia scrapbook (multimedia draft) - appears in the form of a multimedia resource system, where in addition to links to text sites there are also many multimedia materials, including tables, photographs, audio files and video clips, graphic information, animated virtual tours. These files can be easily downloaded by both teachers and students and used as visual demonstration material when studying a specific topic.

3. Treasure hunt is a web resource where, in addition to links to various sites, a teacher can find questions on the content of each site. Using these questions, the teacher can control the cognitive activity of students. At the end of the search, one more general question can be asked on a comprehensive understanding of the topic. A detailed answer will be received for this request, which will include answers to more detailed questions for each of the sites.

4.Subject sample is a site that occupies the next level of complexity compared to the previous resource. It also contains links to text and multimedia materials from the global Internet. As part of working with this resource, the user must not only familiarize himself with the material, but also express and argue his opinion on the issue under study.

5.Webquest (Internet project) is the most complex form of educational Internet resources. This resource includes a scenario for organizing project activities on a topic chosen by a teacher using Internet resources [8].

Here are some examples of internet lessons:

Dave's ESL Cafe enables teachers to search through a wide variety of jobs. Exploring the world is also a great opportunity to give back to the world community by teaching English, while discovering a new culture and country. Dave s ESL Caf has a wide variety of information and resources available and is one of the best resources for ESL teachers worldwide. A popular area is the "Ideas Cookbook" segment for teachers. This page provides teachers with ideas to keep lesson plans new and interesting. As many teachers know, this is one of the great challenges of teaching in any language. Also this website provides a number of excellent tools for students. Many especially enjoy the section that provides students with insight into the most popular slang terms used in the English language. In addition, taking quizzes helps students identify their strengths and weaknesses. Teachers can also use these quizzes to test their student's overall comprehension [9].

Kahoot - is a game, learning platform is used as an educational platform at schools and other educational institutions. The Kahoots educational games are a multi-choice quiz that generates users and are accessible through a web browser.

Kahoot can be an introduction to familiarize students, for formative assessment, or as a break from classroom activities. It also includes trivia quiz [10].

News web sites - from an idea by Donna Arbuthnot.

Students can compare a major news story across different sites - all at the click of a mouse. One idea is to compare an American news site with an English news site. The teacher needs to 
access those sites himself before he goes into the class, and he needs to check that the same news items are being reported on both sites. Just to compare the content and style. It leads on quite well to follow up activities like the students creating their own web site, or the teacher can get them to compare newspapers in their own country in their own language with the American and the English sites [11].

Research / role play - from an idea by David Eastment. The students need to choose a new car or house, with a maximum price of perhaps $£ 20$ 000. The students go to different sites, select a car, and then put the picture of the car inside a word document with an explanation of why they chose that model and what features it had. This approach could be endlessly adapted. Students can research for any variety of projects or situations [12].

Piktochart is an all-in-one visual communication maker.

It allows you to turn text- or data-heavy content into a visual story that is understandable to any type of audience. Easily create reports, presentations, infographics, social media graphics, or posters using just one web application.

Some other features:

- Interactive charts and maps

- Linking of Excel or Google Sheet files for data visualization

- HTML output (hyperlinking) and image download

- Easy customization to brand colors based on uploaded logo

- Friendly user interface [13].

Quizizz - is another amazing online testing program.

Quizizz is a solid web-based student assessment tool, very similar to Kahoot! However, unlike Kahoot, in the Quizizz service, the teacher can manage the class, for the individual work of each student. The teacher can create his own tests, edit them. All students receive the same tasks, but each student on their device receives a random sequence of questions and will work with the test at their own pace.

The display shows the difference from Kahoot not only the answer symbols, but also the whole question with an image, which can be enlarged if desired [14].

More advanced teachers use Microsoft's product - the Teams corporate platform. It includes chat, online meetings, various applications. Also, the product is the ability to exchange and collaborate with sources. The Teams platform, as conceived by the developers, can replace services such as Zoom, Google Docs, Trello, and other tools. The basic version of Microsoft Teams is completely free to use.

The main advantages of the Team: division of work and tasks into teams; the possibility of an unlimited number of users; storage for files; more than 250 integrated applications for almost any educational task [15].

\section{Conclusion}

To sum up, online education is one of the main trends in the educational process today. Work with electronic textbooks motivates students to work creative. This is the environment that a child is accustomed to: gadgets and computer technology make school activities interesting and encourage the generation of new ideas.

Internet resources provide great assistance in learning foreign languages. This is mainly due to the fact that when using the Internet as a means of teaching a foreign language, many of the goals and objectives of training and education are best possible. Thus, Internet resources contribute to the development of self-educational activity aimed at the development of new experiences.

\section{Gratitude}

I am grateful for my Korkyt Ata University for giving me the chance to explore what I wanted to know. Thanks to their help, I can show today's problem. 


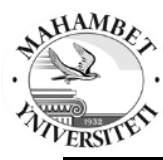

[1] Pollard Lucy. (2008) Lucy Pollard's Guide to Teaching English. [In English].

[2] Liu, F., Black, E, Algina, J., Cavanaugh, C., Dawson, R. (2010). The validation of one parental involvement measurement in virtual schooling. Journal of Interactive Online Learning, 9(2), 105-132 [In English].

[3] Usher, K., Bhullar, N., Durkin, J., Gyamfi, N., Jackson, D. (2020). Family violence and COVID-19: Increased vulnerability and reduced options for support. International Journal of Mental Health Nursing, 29(4), 549 [In English].

[4] Beck, D, Maranto, R., \& Lo, W.-J. (2013). Determinants of student and parent satisfaction at a cyber charter school. The Journal of Educational Research, 107(3), 209-216 [In English].

[5] Rideout, V. J., \& Katz, V. S. (2016). Opportunity for all? Technology and learning in lower-income families. A report of the families and media project. The Joan Ganz Cooney Center at Sesame Workshop. [In English].

[6] Diaz-Rico Lynne T. Strategies for Teaching English Learners. (3rd edition), (2017), 528. Pearson [In English].

[7] The site of main event and IT news of Kazakhstan. Retrieved from: https://bluescreen.kz/articles/derzhi-distanciju-onlajn-obrazovanie-v-kazahstanel [In Russian].

[8] Alsagoff L., McKay S.L., Hu G., Renandya W.A. (2012). Principles and Practices for Teaching English as an International Language. Routledge, New York [In English].

[9] The site of American TESOL Institute. Retrieved from: http://www.americantesol.com/daves-esl-cafe.html?no_redirect=true [In English].

[10] The site is the free encyclopedia - Wikipedia. Retrieved from: https://ru.wikipedia.org/wiki/Kahoot! [In Russian].

[11] Swan M. (2017). What is happening in English? // English Teaching Professional, 40, 69-74 [In English].

[12] The website of British Council. Retrieved from: https://www.teachingenglish.org.uk/ article/using-internet-2 [In English].

[13] The teaching website of Piktochart. Retrieved from: https://chrome.google.com/ webstore/detail/piktochart/ojgpilphbpmpjlicfhhkgnfbedaeegil?hl=ru [In English].

[14] The site of pedagogical practice - Didactor. Retrieved from: http://didaktor.ru/quizizzeshhe-odna-lyubopytnaya-programma-onlajn-testirovaniyal [In Russian].

[15] The website of Microsoft Teams. Retrieved from: https://www.microsoft.com/enus/microsoft-teams/group-chat-software [In English].

\section{Келдібай А.Т., Жусупова Р.Ф. \\ АҒЫЛШЫН ТІЛІН ОНЛАЙН ОКЫТУДА ҚОЛДАНЫЛАТЫН ВЕБ- САЙТТАРДЫН ЖАНА ФОРМАЛАРЫ}

Андатпа. Мақала орта мектепте ағылшын тілін оқытуда білім беру интернетресурстарын пайдалануына арналады. Білім беру интернет-ресурстардың ұғымы мен мәні зерттеліп, оларды таңдау кезінде мұғалімдер қандай критерийлерді ұстану, интернетресурстар арқылы шет тілін қолданудың қандай ерекшеліктерін ескеру қажеттілігі қаралады. Мақалада пандемия кезіндегі ағылшын тілін оқыту әдістемесіне Интернет пен компьютерлік технологияның зор әсерін тигізетін білімнің жаһандану құбылысы қарастырылады. Сонымен қатар, шетелдік әріптестердің шет тілін оқытудағы жаңа идеялары мен бағыттарына тоқталды. Сонымен қатар, оқытудың қазіргі кезеңінде шет тілін оқыту үшін қолдануға болатын интернет-ресурстардың түрлері сипатталған. Интернет - шет тілінің зерттелген тілі, мәдениеті мен дәстүрлері, оның шындығы мен ерекшеліктері туралы үлкен ақпарат көзі. Ақпараттық технология ағылшын тілін оқыту саласында маңызды рөл атқарады, сондықтан бұл мақалада оқытудың жаңа әдісін үйренуге арналған ең жақсы онлайн -технологиялар 


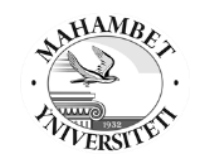

ұсынылған. Мақаланың мақсаты - ағылшын тілін оқытудың тиімділігін арттыру, оқушылардың шығармашылық қабілеттерін дамыту үшін ақпараттық технологияларды қолдану. Мақалада Интернетте студенттерге және тілге арналған әр түрлі онлайн оқыту технологиялары ұсынылған.

Кілт сөздер: онлайн интернет, интернет-ресурстар, білім, агылшын тілі, онлайн оқыту, интернет қызметтері, технологиялар, веб -сайттар.

\section{Келдибай А.Т., Жусупова Р.Ф. \\ НОВЫЕ ФОРМЫ ИСПОЛЬЗОВАНИЯ ВЕБ-САЙТОВ В ОНЛАЙН-ОБУЧЕНИИ АНГЛИЙСКОМУ}

Аннотация. Статья посвящена использованию образовательных интернет-ресурсов для преподавания английского языка в средней школе. В этой статье изучались понятия и суть образовательных интернет-ресурсов, каким критериям должны следовать учителя при выборе интернет-ресурсов, какие особенности использования иностранного языка с помощью интернет-ресурсов следует учитывать. В данной статье рассматривается явление глобализации образования, повлекшее за собой колоссальное влияние интернета и компьютерных технологий на методику преподавания английского языка в период пандемии. Также здесь показаны последние идеи и тренды зарубежных коллег по преподаванию иностранного языка. Кроме того, в этой работе описываются виды интернетресурсов, которые могут использоваться для обучения иностранному языку на нынешнем этапе обучения. Интернет - огромный источник информации об изучаемом языке, культуре и традициях иностранного языка, его реалиях и особенностях. Информационные технологии играют важную роль в области преподавания английского языка, таким образом, в статье предлагаются лучшие онлайнтехнологии для изучения нового метода обучения. Целью статьи является использование информационных технологий в повышении эффективности преподавания английского языка, развития творческих способностей учащихся. В статье даны различные онлайн обучающие технологии доступные в Интернете для студентов и языка.

Ключевые слова: интернет, интернет-ресурсы, образование, английский язык, обучение онлайн, интернет-услуги, технологии, веб-сайты. 